Cahit Mete Oguz

Simon Fraser University

\title{
An Analysis of the Socio-Economic Viewpoints within the Writings of Patriarchs Athanasios I and Philotheos Kokkinos
}

Athanasios I, patriarch of the Byzantine church, left a memorable written legacy. His numerous letters to the emperor and other officials show he was an active and involved individual not just in religious issues, but in nearly all spheres of life. Some of these letters are particularly interesting for purposes of studying the society and economy of early fourteenth century Constantinople and its hinterland. The most interesting letters for this purpose date from Athanasios' second patriarchate period (1303-1309), which was a period of acute military and economic crisis in Byzantium. As a result of this unique source, it is possible to see many of Athanasios' suggestions and views about economic regulations, monastic society, the grain trade and general urban life. For this information, we mainly have an infamous Catalan mercenary company which went rogue to thank, since they acted as somewhat of a catalyst for the troubles which plagued the Byzantine countryside in these years. The information Athanasios provides can be fruitfully compared with the information provided by the writings of Philotheos Kokkinos, another patriarch from half a decade later. Kokkinos was an exceptionally talented hagiographer; one of his such ventures describes the Miracles of Gregory Palamas. Although providing less direct information on Constantinople's social and economic life, this text still furnishes some interesting points about city life, particularly about Thessaloniki, the home city of both Kokkinos and Palamas. This paper will attempt to analyze the views of these two patriarchs on Byzantine society and its economy, and how they should operate.

The fourteenth century was a period when the Byzantine state frequently found itself in acute political, economic and military crises. The territories of the empire had been shrinking for several decades. The post-1261 period, when the Lascarids had re-established Roman control over Constantinople after the Latin Fourth Crusade had held it for 60 years, was marked by increasing tension and hostility between European powers and Byzantium. This divide manifested itself in a religious dispute between the Papacy and the Orthodox Patriarch of Constantinople. However, acute pressure, especially from the East, resulted in Byzantium often being obliged to seek assistance from these very same European powers. This help was often conditional on the Byzantine acceptance of Papal supremacy and giving way in long-existing religious debates. Understandably, such measures were very unpopular with the broader population, especially in Constantinople, where recently the populace had witnessed a sacking and conquest by these very same Western powers. Internal and external pressures meant that emperors and patriarchs were often placed in losing scenarios where a choice had to be made that was bound to have negative consequences for either one side or the other. 
Athanasios I, born around 1230 in Adrianople, became a famous ascetic monk with a large horde of followers flocking to him as pilgrims. ${ }^{1}$ Before the early fourteenth century, the period which makes up the subject of this study, the church had been torn by the Union of Lyons in 1274, and also by the ongoing struggles between the followers of patriarchs Joseph and Arsenios. ${ }^{2}$ Eventually, by the late 1280's emperor Andronikos II, hearing of Athanasios' saintliness, ${ }^{3}$ decided to appoint him as patriarch, thinking that it may partially satisfy the antiArsenite groups in ecclesiastical spheres. ${ }^{4}$ He held the position of patriarch between 1289-1293. However, his ascetic approach and very strict discipline were not well received by the clergy, and changes in policy such as confiscating the funds of monasteries and sending bishops back to their sees, made him unpopular. ${ }^{5}$ In 1293 Athanasios had to leave his office as a result of the hatred he had garnered among important ecclesiastical and monastic individuals. ${ }^{6}$ However, in 1303, Andronikos II reinstated Athanasios as patriarch for two main reasons. First and foremost, Athanasios, while he was patriarch, had written an anathematizing letter directed to the emperor, which he was unable to take back as a layman, but instead he needed to be reinstated to officially nullify it. Secondly, the emperor witnessed Athanasios' prophetic capabilities, such as Athanasios's ability to guess two earthquakes in one day and was impressed by him. ${ }^{7}$ As such, Athanasios was appointed patriarch once again, despite his poor relationship with the clergy, from 1303-1309. During this period of intense famine and crisis, Athanasios acted as a champion of the poor and constantly fought to alleviate their conditions of starvation and suffering, even at the expense of his relationship with wealthy lay and ecclesiastical figures in the capital. He was also a vocal opponent of the Latins and an anti-Unionist patriarch, another matter of alignment with Andronikos. When Athanasios finally died in 1309, he was seen as a saint by the common populace of Constantinople and his relics were thought to have important healing powers. ${ }^{8}$ Our main primary sources for Athanasios' life, including the above information, are the histories of Pachymeres and Gregoras, a few hagiographies, and his own writings. Hagiographies written by

\footnotetext{
${ }^{1}$ Athanasios I, The Correspondence of Patriarch Athanasios I: Letters to the Emperor Andronikos II, Members of the Imperial Family, and Officials, trans. Alice-Mary Talbot (CFHB Vol VII, 1975), xvi.

${ }^{2}$ John L. Boojamra, Church Reform in the Late Byzantine Empire: A Study for the Patriarchate of Athanasios of Constantinople, Analekta Vlatadon 35 (Thessalonike: Patriarchal Institute for Patristic Studies, 1982), 14-15. One of Andronikos II's first actions was to reject the Union of Lyons and restore the old orthodox tradition - which even meant denying his own father, Michael VIII, a proper Christian funeral. The Arsenites were also a major issue in this period, they consisted of a broad movement which gained support from the Laskarids of Asia Minor. They claimed that patriarch Arsenios had been wrongly disposed of in place of patriarch Joseph.

${ }^{3}$ Initially, in 1282, Andronicos II had heard of Athanasios' asceticism and saintliness and wanted him close by. He therefore arranged for Athanasios to be positioned in the nearby monastery of the Great Logariastes, so that he could visit him frequently.

${ }^{4}$ J. Meyendorff, "Spiritual Trends in Byzantium in the Late Thirteenth and Early Fourteenth Centuries", The Kariye Djami, vol. 4, ed. P. Underwood (Princeton, N.J., 1975), 96. The Arsenites were also associated with the Zealots, who were seen as being a very extreme faction, particularly active in Thessaloniki.

${ }_{6}^{5}$ Athanasios, xix.

${ }^{6}$ Ibid., xix.

${ }^{7}$ Ibid., xx, xxi, xxii.

${ }^{8}$ Ibid., xxvii
} 
the monks Theoktistos the Stoudite and Ignatios describe many posthumous cures attributed to Athanasios. ${ }^{9}$

This study focusses on the period of Athanasios' second patriarchate, as it was a period of acute social and economic crisis, and the patriarch's letters from this period include many digressions on non-religious topics. Between 1303 and 1309, the Byzantine state was concerned with the what was termed the "Catalan problem." The Catalans were an army of mercenaries numbering about $6500,{ }^{10}$ hired by the Byzantine state in 1303 to help fight against the invading Turks. Despite successfully repelling the Turks, the situation quickly deteriorated into open hostility between the Catalans, who were plundering the Byzantine countryside, and the Byzantines. Even the initial Catalan arrival was very problematic; the mercenary army had hired Genoese ships to reach Constantinople by taking out a loan with Andronikos II named as a guarantor for payment. When the army arrived, the Genoese immediately demanded payment from the emperor, escalating tensions between the Catalans, Genoese and the emperor. ${ }^{11}$ During the height of this financial crisis, the emperor was forced to enforce a new tax, the sitokrithon, to help finance the state. ${ }^{12}$ This tax forced the peasantry to give six modioi of wheat and four of barley to the imperial treasury, and deducted one-third of the salaries of state officials. In August 1304 the first major Byzantine-Catalan conflict began when Andronikos decided to cut the salaries of the Catalan mercenaries. ${ }^{13}$ In his earlier letters, Athanasios had warned the emperor about the Catalans, even before the situation developed into warfare with them. In his letters dating from 1303 to1304, Athanasios wrote to the emperor accusing the Catalan mercenaries of acting as an advanced Western guard aimed at conquering the Roman Empire. ${ }^{14}$

In July 1305, the Byzantine army was decisively defeated at the Battle of Apros. ${ }^{15}$ This battle decimated the army, evidenced by their ability to muster only about 150 soldiers for the defence of the important granary city of Rodosto in Thrace when the Catalans attacked it shortly after the Battle. The Catalans began occupying the whole of Thrace and laying siege to its cities one by one. ${ }^{16}$ The Catalans knew the importance of Thrace as a grain-producing region and, especially, the important stockpiling "granary" cities, such as Rodosto, which they captured after a year-long siege in July 1306. ${ }^{17}$ The Empire was on the brink of collapse, as one of its most

\footnotetext{
${ }^{9}$ Alice-Mary Talbot, Faith Healing in Late Byzantium: The Posthumous Miracles of the Patriarch Athanasios I of Constantinople by Theoktistos the Stoudite (Brookline, Mass.: Hellenic College Press, 1983), 24.

${ }^{10}$ Angeliki E. Laiou, The Foreign Policy of Andronikos II 1282-1328 (Cambridge, Mass.: Harvard University Press, 1972), 134. There is a slight ambiguity to the exact number of Catalan soldiers who actually arrived in Constantinople in September 1303. Laiou mentions that Pachymeres gives the number to be about 8000 , whereas Gregoras reduces this number to 2000. She suggests that the most accurate numbers come from Muntaner, who gives the total number to be about 6500 (1500 cavalry, 4000 Almugavars, 1000 foot-soldiers).

${ }_{11}^{11}$ Ibid., 135.

${ }^{12}$ Boojamra, Church Reform in the Late Byzantine Empire, 199. This information reaches us through the historical writings of Pachymeres and Gregoras, who both describe this tax being implemented in 1304 .

${ }^{13}$ Laiou, The Foreign Policy of Andronikos II, 136.

${ }^{14}$ Boojamra, Church Reform in the Late Byzantine Empire, 198.

${ }^{15}$ Angeliki E. Laiou, "The Provisioning of Constantinople During the Winter of 1306-1307”, Byzantion 37 (1967), 98.

${ }^{16}$ Laiou, The Foreign Policy of Andronikos II, 142-46.

${ }^{17}$ Laiou, "The Provisioning of Constantinople, 97.
} 
important grain supplies, ${ }^{18}$ the Thracian region, was completely disrupted. Despite Andronikos' setup of a protective "gendarmerie" in 1305 to protect the peasants as they cultivated their fields, it was to no avail. Thrace was lost. ${ }^{19}$

Two events led to the continued existence of the Byzantine empire: Andronikos' scorched earth policy which he implemented in the Winter of 1306/1307, which forbade peasants from cultivating any land in Thrace, ${ }^{20}$ and extensive Genoese support, especially naval support. The Genoese wanted to preserve Byzantium to maintain their commercial hubs in the region. ${ }^{21}$ For Andronikos the turning point appears to be the fall of Rodosto in the summer of 1306, a major granary for the empire which the Byzantines were unable to defend even though the siege had lasted a whole year. The sad contingent of only 150 Byzantine soldiers sent to defend it shows the direness of the situation for the empire. After the fall of Rodosto, Andronikos must have thought that a really radical, almost too radical, measure was required to combat the Catalans once and for all. Despite multiple voices urging against it, including Athanasios, he implemented his famous scorched earth policy. Andronikos II's scorched earth policy gambled that the Catalans would starve and be forced to leave Thrace first, before Constantinople starved and fell. ${ }^{22}$ This event will be discussed in depth in the remaining paragraphs, by analyzing Athanasios' comments on the situation.

Further, an influx of Thracian refugees fleeing from the Catalans aggravated the situation in Constantinople, resulting in a population increase even though famine conditions already existed. This exacerbated starvation and supply problems for the Catalans. ${ }^{23}$ By the early Summer of 1307, the gamble had succeeded, and the Catalans were forced to move out of Thrace towards Macedonia due to lack of food. ${ }^{24}$ The Empire also benefitted from the hardiness of the local inhabitants of Thrace, in whom Angeliki Laiou has identified a proto-nationalist resistance. ${ }^{25}$ The locals of Thrace hated most Westerners and, due to the lack of any actual military assistance, they frequently banded into groups of militias to defend their motherland. They were tremendously influential in the continuation of the Empire. ${ }^{26}$

\footnotetext{
${ }^{18}$ Ibid., 96. In the early fourteenth century, the Byzantine empire, and especially Constantinople, had two important grain supplying regions on which it was dependent. One was the Thracian plains, another was the Black Sea coasts. The first source was disrupted due to the Catalan events. The Black Sea grain required Italian ships to transport it and bring it to the capital. As it was dependent on the Italians, the Italians began profiteering off the famine conditions in the capital by demanding very high prices for all grain they brought in. In addition, the Italians exported part of this grain from Constantinople back to their home cities, despite the terrible famine conditions in the capital.

${ }^{19}$ Ibid., 104.

${ }^{20}$ Ibid., 101.

${ }^{21}$ Laiou, The Foreign Policy of Andronikos II, 147-48. After the events of 1304-1308, the Genoese had truly taken over the commercial aspects of the empire. Also, Byzantium became completely dependent on the Italians for their naval defenses after this period.

${ }^{22}$ Laiou, "The Provisioning of Constantinople, 92.

${ }^{23}$ Ibid., 91.

${ }^{24} \mathrm{Ibid}, 104$.

${ }^{25}$ Laiou, The Foreign Policy of Andronikos II, 167.

${ }^{26}$ Ibid., 159.
} 
Patriarch Athanasios' view of the Emperor's extreme policy is quite obvious from his frequent vocal objections about the matter. In one letter he comments, "Leaving the land unplanted will bring more destruction than profit." ${ }^{27}$ Further on in the same letter, he adds, "Do not prevent the people from tilling the land." This letter is dated from autumn 1306, meaning it was composed just after Andronikos had first implemented his scorched earth policy, which he had decreed after the fall of Rodosto in the late summer of 1306. Athanasios describes the suffering and lack of food which particularly affected the poor and needy, and argues he cannot support such a harsh gamble as a tactic against the Catalans. Pachymeres' history supports Athanasios' concerns, describing the suffering of the already famine-stricken capital. ${ }^{28}$ Athanasios, as a champion of the poor, felt unable to watch as they starved to death. He describes walking in the streets, approached by people asking him for food. He states, "the poor complain in unison about the scarcity of food." 29

Athanasios attributes the famine partly to the "Latins" (Italians), suggesting that "He who raises the price of grain is cursed by the people". ${ }^{30}$ Athanasios refers here to Italians who were transporting the Black Sea grain to the capital, ${ }^{31}$ in addition to local middlemen who were also seeking to profit from the grain scarcity in the city. In Athanasios' letters, profit-seeking is one of the most frequently utilized condemnations; he clearly believed that such profit-seeking activities were increasing the misery of the common people. The capital was entirely dependent on this grain, and the Italians, according to Athanasios, were profiteering from this dependence by raising prices. Athanasios curses them for such acts of profit in the face of starvation of the people. He critiques Italians for permitting the export part of the grain back to their home cities despite the famine. ${ }^{32}$ In a few different letters, Athanasios repeatedly begs the emperor to not permit the export of grain outside the capital and to regulate the price and sale of grain and bread to prevent the threat of starvation. ${ }^{33}$ Athanasios writes, "no other official except the pious man I have mentioned ${ }^{34}$ may be permitted to control the administration of the grain supply, this official should not allow grain to be bought up by men who will raise its price." ${ }^{35}$ The extent of Athanasios' non-religious involvement in the affairs of the empire is interesting considering his employment in the religious office. Athanasios is very critical and outspoken of the emperor himself. He repeatedly attributes the famine to the emperor's mishandling of affairs. Athanasios employs emotional phrases such as, "look at your children who are starving for bread," to encourage emperor to heed his warnings. ${ }^{36} \mathrm{He}$ accuses the emperor of receiving bribes from the

\footnotetext{
${ }^{27}$ Athanasios I, 161 (Letter 67).

${ }^{28}$ Pachymeres, IV, 691.

${ }^{29}$ Athanasios I, 170 (Letter 72).

${ }^{30}$ Ibid., 181 (Letter 72)

${ }^{31}$ Ibid., 394. Both the Genoese and the Venetians were active in transporting grain which was harvested from the coasts of the Black Sea region to the capital, and then conducting a lucrative business by exporting this to Italy.

32 Ibid.

${ }^{33}$ Ibid., 187 (Letter 74), 183 (Letter 73), 245 (Letter 93), 257 (Letter 100).

${ }^{34}$ In a different letter (Letter 93), Athanasios had given the name of a "pious man" called Dermokaites as his suggestion for being made head of the grain commission - this letter is alluding to this fact.

35 Ibid., 183 (Letter 73).

${ }^{36}$ Ibid.
} 
Italians to allow them to raise the prices and continue exporting grain out of the capital. ${ }^{37}$ Not many people were able to call an emperor a "corrupt person" and accuse him of receiving bribes and get away with it. The power and influence that Athanasios held over the timid Andronikos are apparent when we look at his letters.

In the tenth century, control mechanisms and regulations existed over the sale prices and weights of grain, as described in the Book of the Prefect. It appears that by the early fourteenth century, these regulative measures had ceased to function, as suggested by Athanasios' many attempts to re-establish them. Athanasios boldly wrote: "I demand from your majesty that above all the honest purchase of grain and bread be carefully controlled, and that this supervision be carried out by a man noted for his honesty, Dermokaites the sebastos." 38 Here Athanasios is very blunt and direct with the emperor, demanding that his advice be heeded; he also recommends somebody to head the grain commission. In a subsequent letter it is apparent that the emperor did take up Athanasios' advice to create such a regulatory commission, including his suggestion that Dermokaites be appointed head of it: "Since your majesty has commanded that supervision be made of bakers, who they are and how many, and how they buy and sell, and also that the ships which transport the grain be closely supervised... I ask that men be chosen to serve together with Dermokaites the sebastos to achieve this purpose." ${ }^{39}$ Athanasios proceeds to name two demarchs called Antiocheites and Ploummes to be appointed to work in the grain commission to assist Dermokaites. ${ }^{40}$ The new regulations implemented by the emperor also feature clauses that abolish middlemen who were raising the prices of grain and causing suffering to the poor ("'iv $\alpha$

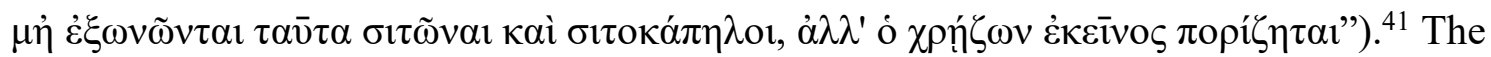
acceptance of Athanasios's demarch recommendations shows extent of the patriarch's influence over the emperor who appears to be accepting most of Athanasios' demands despite his harsh tone. In the last centuries of Byzantium, many patriarchs were forced to resign due to conflicts with the emperors, ${ }^{42}$ but in Athanasios' case, his profound influence over the emperor seems to have manifested itself in the emperor protecting him. This close relationship likely stems from the period before Andronikos first appointing Athanasios as patriarch in 1289, during which he was already very impressed by the famous ascetic monk.

In addition to local middlemen, another local problem which outraged Athanasios was wealthy people who were hoarding grain and bread due to the famine conditions in the capital. ${ }^{43}$ During any sort of famine, it is not surprising that the wealthy would use their resources to collect and store grain and all sorts of food; this practice obviously tends to exacerbate the famine and worsen conditions for poor people. Athanasios is quite harsh in his tone towards such people, writing, "for it is by the oppression of these poor people that they (the wealthy who were

\footnotetext{
${ }^{37}$ Ibid., 181 (Letter 72).

${ }^{38}$ Ibid., 243 (Letter 93)

${ }^{39}$ Ibid., 257 (Letter 100).

${ }^{40}$ Ibid.

${ }^{41}$ Athanasios I, 429.

${ }^{42}$ Donald M. Nicol, Church and Society in the Last Centuries of Byzantium (Cambridge: Cambridge University Press, 1979), 21.

${ }^{43}$ Ibid., 267 (Letter 106).
} 
hoarding grain) wish to acquire their accursed wealth." ${ }^{44}$ Negative remarks towards those with material wealth are frequent in Athanasios' letters. In the above passage, which underlines the oppression of the poor by the rich, there is almost a sort of proto-Marxist undertone detectable in Athanasios ideology as he separates society into several parts similar to classes: the middlemen, the rich, the poor. He suggests that "every wealthy noble either support a certain number of refugees until summertime, or contribute to a relief fund," and stresses that it is the duty of the rich to help the poor. ${ }^{45}$ This binary separation he creates in his writings appears to divide society into those obsessed with acquiring material wealth at the expense of others, and those who are not. The implications is that the people who are not doing this are either too poor to be able to accumulate any wealth anyway, or are decent moral, Christian people who do not permit others to suffer.

Despite all of his successes, Athanasios appears quite self-critical, suggesting "I am stuffed to satiety, and beyond my needs, while the poor are not only oppressed by other calamities but are also crushed and destroyed by famine and cold." ${ }^{46}$ Here, Athanasios appears to be feeling guilty that he enjoys necessary provisions while the poor do not. He is dangerously close to falling into the 'bad' side of the binary dichotomy he repeats in his writings. Such phrases within his writings suggest that his concerns for the poor are genuine, as Athanasios felt that he had let them down personally. In many of his letters dating from 1306 and 1307 , Athanasios generally takes the side of the poor, including making personal efforts on their behalf. In one such situation, he set up soup kitchens in the capital for the poor, to help alleviate their starvation: "I decided to have a gruel boiled for the needy and miserable." 47 The funding for these soup kitchens came from "Athanasios' personal funds," meaning church funds. ${ }^{48}$ This resulted in some influential ecclesiastical figures losing some of their wealth, and furthered their dislike of Athanasios. ${ }^{49}$

Athanasios' monastic background may have led to his interest in certain socio-economic issues pertaining to monasteries. In one of his letters, Athanasios urges the emperor to issue a decree to prevent fiscal agents from operating on monastic properties. He argues that the tenants of monastic lands should pay morti directly to the monks. The monastery would then pay the tax directly to the state, as the fiscal agents frequently pocket this money instead of delivering it to the state. ${ }^{50}$ Athanasios thus demonstrates a mistrust of fiscal agents. During the terrible losses of land in Anatolia, and particularly following the catastrophe of Bapheus (1302), Athanasios told the emperor that the military demise of the empire could be reversed by simply controlling these dishonest fiscal agents, thereby securing proper revenue flow to the state coffers, which would fund a stronger army. ${ }^{51}$

\footnotetext{
${ }^{44}$ Ibid.

${ }^{45}$ Ibid., 53 (Letter 22)

${ }^{46}$ Ibid., 195 (Letter 78)

${ }^{47}$ Ibid., 197 (Letter 78)

48 lbid.

${ }^{49}$ Laiou, "The Provisioning of Constantinople, 106.

${ }^{50}$ Athanasios I, 59 (Letter 27), 339.

${ }^{51}$ Boojamra, Church Reform in the Late Byzantine Empire, 156.
} 
In this period of financial crisis (1306-1307), the emperor was trying desperately to raise money to fund the army and pay off the Catalan mercenaries. On such attempt was to roll back the tax exemption that monastic lands received. The emperor attempted this in a somewhat indirect way, by decreeing that revenues from all ecclesiastical and monastic properties should be diverted to fund the military, arguing this was the most urgent necessity for the survival of the empire. ${ }^{52}$ By the fourteenth century, the amount of monastic lands had greatly increased and were contributing to the social and economic weakness of the empire. ${ }^{53}$ In addition to being an economic liability due to the numerous tax exemptions that they enjoyed, monastic lands were also seen as a source of consistent manpower drain to the state. Young men who could become useful members of the military or land-cultivating population were embracing monastic life, which, according to Charanis, was a life lost to society. Athanasios, being from a monastic background, was not against this general system, but he was critical that the revenue of monastic lands was being handed out as pronoia ${ }^{54}$ to soldiers. ${ }^{55}$ Andronikos tried to bolster the deteriorating pronoia system, as he saw it as a precursor for a strong military, insisting that revenue sources given to churches and monasteries should instead be used to pay soldiers. ${ }^{56}$ Despite Athanasios' obvious awareness that such measures were necessary in dire times, he felt obliged to defend ecclesiastical and monastic influence from the grasp of secular powers. His vocal mistrust of tax collecting agents, and his lack of belief that they would honestly collect such revenue, may have been one of the primary motivations for his objections. The inability of the state to properly enforce tax collection could be argued to be sufficient justification for Athanasios' rejection of the emperor's plans on a moral basis. Additionally, while Athanasios was not against monastic ownership of large amounts of land, he did underline that such wealth should be used for the people, and not to further the agendas of a few individuals. ${ }^{57}$ Overall,

\footnotetext{
${ }^{52}$ Ibid., 159.

${ }^{53}$ Peter Charanis, "On the Social Structure and Economic Organization of the Byzantine Empire in the Thirteenth Century and Later", Byzantinoslavica 12 (1951), 108, 113-116. Monastic properties were increasing due to several reasons; donations to monasteries (in wealth or land), direct monastic land acquisition by buying from other landholders (specially to eliminate remnants of private property within their own lands), and also by gaining land through grants from the emperor (seen in chrysobulls issued by the emperor).

${ }^{54}$ The pronoia system, from the late-eleventh century onwards, was a means of distributing the fiscal rights of a piece of land to an individual (often soldiers). It was significantly different from Western European Feudalism in which military obligations existed and in which the peasantry had less legal rights. These pronoia grants were handed out by the emperor and could theoretically be withdrawn at any time by the emperor, yet, during the fourteenth century they had started devolving into somewhat permanent land grants. The most up to date and comprehensive analysis of the pronoia system can be found in: Mark Bartusis, Land and Privilege in Byzantium: The Institution of Pronoia, Cambridge University Press, 2012.

${ }^{55}$ Athanasios I, 219. (Letter 83), Boojamra, Church Reform in the Late Byzantine Empire, 158. Sources such as Pachymeres inform us that in this period (the early fourteenth century) the Byzantine military was significantly deteriorating due to soldiers abandoning their pronoiai - as a result it is known that many soldiers lost their will to defend these areas. The pronoia system, due to its nature, enabled the holders of the grants to harbor personal interests in maintaining and protecting their peasantry and lands. This was of major importance for the defense of rural areas of the empire, where the state, with its deteriorating military, was often unable to defend itself. For more information see, Charanis, "On the Social and Economic Organization of the Byzantine Empire in the Thirteenth Century and Later", 98.

${ }_{56}^{56}$ Boojamra, Church Reform in the Late Byzantine Empire, 159.

${ }^{57}$ Ibid., 153.
} 
despite being a religious figure which led him to defend ecclesiastical property and financial rights, his letters demonstrate that Athanasios' was remarkably reform-oriented in his acceptance of such policies which would have traditionally been thought to weaken the Church, but that would arguably benefit the state/people.

Another source of conflict between Athanasios and other bishops and monks was Athanasios' insistence on the episcopal residence of bishops. According to him, bishops should remain in their sees, even if the territory fell into foreign hands, such as the Turks or Western Foreigners, because these bishops represented the faithful Orthodox tradition and could be focal points of local opposition to the conquerors. ${ }^{58}$ Athanasios harshly condemns practices such as simony, corruption and receiving bribes among ecclesiastical and monastic communities, and mentions that the emperor should punish these people appropriately. ${ }^{59}$ Because he was disciplined and took pride in his integrity, Athanasios was likely not involved in such deeds and did not countenance others who did were. In another letter, he mentions how "some people are concerned with whatever will contribute to their sensual enjoyment and are not concerned with inhabiting the monasteries in an ascetic manner." ${ }^{60}$ This letter begins with the sentence, "Recently, like every other god thing which was rightly laid down for our generation, it has been forgotten for what reason monasteries have been constructed." ${ }^{61} \mathrm{He}$ continues "[a]las, what a grievous misfortune! How greed has beguiled certain people, to steal without scruple the properties dedicated to God through unlawful acts." "P2 "Properties dedicate to God" refers to monastic properties, and his reference to the "greedy people" was intended to accuse certain bishops of exploiting the monasteries they are in charge of. ${ }^{63}$ Here, he is condemning unfortunate, non-Christian practices associated with monastic life.

Frequently, his criticisms have Christian connotations. Athanasios mentions how such bad practices will bring the "ruin of the Christian flock." ${ }^{64}$ In one of the harshest statements in all his published letters, Athanasios threatened to excommunicate and anathematize anyone involved with grain-dealing, as he says it is better for him to cultivate the wrath of such people and face its consequences than to keep silent in the face of such atrocities. ${ }^{65}$ In this comment, he is utilizing his power as patriarch to threaten excommunication while highlighting his radical stance on non-Christian practices in his description of how he is willing to be killed, rather than remain docile.

Athanasios frequently uses the word $\mu \varepsilon \tau \alpha v o 1 \alpha$ in his letters, which means a change of mind, or more specifically 'repentance.' This is the idea that by turning to God through sincere remorse and regret people can still be saved, as Athanasios, like many Byzantine spiritual leaders, was of the common opinion that sinful and non-Christian practices were leading to the

\footnotetext{
${ }^{58}$ Athanasios I, 21.

${ }^{59}$ Ibid., 153 (Letter 65)

${ }^{60}$ Ibid., 219 (Letter 83)

${ }^{61}$ Ibid.

${ }^{62}$ Ibid.

${ }^{63}$ Ibid., 409.

${ }^{64}$ Ibid., 267 (Letter 106).

${ }^{65}$ Ibid.
} 
downfall of the empire. Yet, according to Athanasios's positive outlook, this curse can still be lifted through repentance. No situation was too bad to be saved, and Athanasios suggested that the empire can always be saved through repentance and reaching out to the Orthodox Christian God. Athanasios also consistently uses the words 'state' and 'church' interchangeably because, for him as a pious churchman, the end of the church would have meant the end of everything, including the polity. ${ }^{66}$ Theoktistos the Stoudite, in his hagiography about Athanasios, ${ }^{67}$ describes him as a figure who excelled at making evil subject good, disregarded all earthly wealth, and completely refrained from anything profane or unorthodox. ${ }^{68}$ These qualities also resonate throughout his letters.

The viewpoints on urban society and the economic situation found in the writings of patriarch Athanasios can be complemented by the writings of another patriarch from half a decade later, the hagiographic work of Philotheos Kokkinos. In addition to twice being patriarch, from 1353-1355 and from 1364-1376, Kokkinos was also one of the most talented hagiographers of the Palaiologan period. ${ }^{69}$ Hagiographies often contain important information on society and economic activities. ${ }^{70}$ Kokkinos was born in Thessaloniki and, for this reason, his hagiographic writings are mainly concerned with saints associated with Thessaloniki. ${ }^{71}$ Kokkinos' writings about the Miracles of Gregory Palamas, shortly before the latter's canonization, exemplify this. This text, located at the end of the manuscript containing the autobiography of Kokkinos, provides valuable information about everyday life in Thessaloniki. Kokkinos states that his own source on Palamas and his miracles was mainly the great steward of the church of Thessaloniki, information he mentions he tried to weave into a narrative. ${ }^{72}$ The motivation for such a text was likely to support canonization of Palamas, which eventually did occur. I would like briefly to discuss some of the types of information that we can retrieve about Byzantine society from this text, before comparing Kokkinos' viewpoints with Athanasios'.

Gregory Palamas, as described by Kokkinos, exemplifies the hardening anti-Western stance amongst Byzantine theologians/intellectuals too, and demonstrates that such feelings were

\footnotetext{
${ }^{66}$ Boojamra, Church Reform in the Late Byzantine Empire, 22.

${ }^{67}$ This hagiography also provides some important socio-economic information. During the course of this text, Theoktistos furnishes us with some information on monastic food storage by stating that 30 modioi of wheat was a satisfactory storage to be used as backup in case of a famine. Stephanos Efthymiadis, The Ashgate Research Companion to Byzantine Hagiography: Volume II: Genres and Contexts (Ashgate Publishing, 2013 ), 402.

68 Talbot, Faith Healing in Late Byzantium, 65-75.

${ }^{69}$ Alice-Mary Talbot and Scott F. Johnson, Miracle Tales from Byzantium, DOML 12 (Cambridge: Harvard University Press, 2012), xxi.

${ }^{70}$ For the Palaiologan period hagiographies help identify the important wealth producing regions of the empire. From these sources Bithynia is usually mentioned as being very bountiful in terms of olive oil and wine production especially, as seen in the Miracles of Zoodochos Pege. Macedonia is shown by the Vita of Makarios Makres as being a region rich in wheat cultivation and orchards. The hagiographies of Gregory of Cyprus discuss the size and demographic composition of countryside estates. Detailed information about rural taxation can be found in the Theodoros Pediasimos' Miracles of Hagioi Theodoroi. This source especially discusses how tax collectors would siphon off more money from the peasants, effectively doubling the tax burden, even though the extra would never reach the state coffers. The Ashgate Research Companion to Byzantine Hagiography: Volume II, 401-404.

${ }^{71}$ Talbot, Miracle Tales from Byzantium, xxi.

${ }^{72}$ Ibid., xix.
} 
not just limited to the lower classes. Palamas was a monk, theologian and intellectual leader of the Hescyhasm movement, literally meaning "a state of quietness," which was an ascetical movement combining mysticism and repetitive prayers with more traditional Christian values. Despite being controversial in its time, and often accused of being Polytheistic or Pantheistic by theologians of the time, Hesychasm is now sanctioned as legitimate by the Orthodox church. In 1347 Palamas was appointed bishop of Thessaloniki. Furthermore, the socio-economic situation had evolved such that by the fourteenth century, the impoverishment of the masses, both in the countryside and the cities, had led to instability, with a handful of aristocratic families holding most of the wealth. This resulted in a great deal of bitterness which Athanasios and Kokkinos allude to in their work.

In one anecdote in the text, Kokkinos describes Palates as a man "of honest character and a gold embroiderer by trade."73 The further discussion of Palates suggests gold embroiderer was a highly respected trade in Byzantine society. Kokkinos tells the story of Palamas arriving at Palates' house, where Palates is busily working with his fellow artisans. ${ }^{74}$ The distinction between a house and a workshop/workplace is very blurred and, as seen in this story, they are frequently the same place. According to Kokkinos, this home-business sort of arrangement is perfectly respectable, as there is no indication Kokkinos is looking down on the man. Because Kokkinos is a patriarch and representative of the higher echelons of society, this statement indicate acceptance of such arrangements among the broader Byzantine high society in general. However, Kokkinos can be scornful towards others in society of whom he does not approve of. For instance, he describes a man as "not one of the insignificant inhabitants of the city, but wellborn and notable." 75 Society, according to Kokkinos, is mentally separated into distinct segments, with the lower end being viewed as insignificant. This is most probably meant as a praise for the man being described rather than a criticism of commoners, yet still the meaning appears to resonate through all levels of society, as it is part of the social worldview of Kokkinos. $^{76}$

Kokkinos informs us about the challenges of everyday life, such as the difficult journey from Constantinople to Thessaloniki during winter times. He describes how many people would post-pone their journey for times of more favourable weather because of the difficulty in travel and access in the cold season. ${ }^{77}$ According to Kokkinos, travel was heavily dependent on the weather. In a different hagiography, Kokkinos discusses the life of large landholders; he describes a large landholding near the outskirts of Thessaloniki and how peasants would work the land as wage labourers; they were free but poor peasants. ${ }^{78} \mathrm{He}$ describes the bad working conditions and timetable of these day labourers, providing us with some important information

\footnotetext{
${ }^{73}$ Ibid., 319 (Chapter 7).

${ }^{74}$ Ibid., 320 (Chapter 7).

${ }^{75}$ Ibid., 335 (Chapter 12).

${ }^{76} \mathrm{He}$ is not criticizing the lower classes in a direct manner, but using the idea that not being a lower class is worthy of mention instead. This indirectly is actually a belittlement of the lower classes.

${ }^{77}$ Ibid., 387 (Chapter 23).

${ }^{78}$ The Ashgate Research Companion to Byzantine Hagiography: Volume II, 403.
} 
on them. These snippets from the writings of Kokkinos provide a glimpse into his socioeconomic perception of especially the laboring classes - on the one hand he is recognizing their importance for the well-being of the empire, but on the other hand, his attitude is generally disdainful towards the social status and culture of peasant or a commoner of the masses. This is especially interesting when compared against his criticisms of Constantinopolitan high culture.

In his writings, Kokkinos displays enthusiasm for his home town of Thessaloniki. Talbot argues his writings reflect a sort of city-scape nationalism. Kokkinos explains that though Palamas welcomed and assisted inhabitants of other regions, he did not neglect residents of places other than Thessaloniki. ${ }^{79}$ Yet, certain xenophobic tendencies are visible in Kokkinos' stories. In one instance, Kokkinos describes how a pilgrim from a foreign land had come to receive a cure from Palamas. However, Palamas' reaction is less than welcoming: "because he was suspicious of the man's character and the way he praying, surmising that he was not there for a good reason, he first asked him what was wrong with him." 80 As this quote highlights, people with different customs were viewed suspiciously and their 'otherness' was seen as a possible threat, a common theme in Byzantine literature. ${ }^{81}$

Byzantinists often use saints' lives to study social history ${ }^{82}$ and Kokkinos' writings contain an abundance of information on the social makeup of Thessaloniki. For example, Kokkinos describes how a certain citizen of Thessaloniki ardently defended Palamas' view of the truth and Palamas' election as archbishop, which was being rejected by the Zealot factions. ${ }^{83}$ Kokkinos explains how this man was subjected to terrible plots and attacks from the Zealot factions due to his defence of Palamas. The Zealots were a political-religious faction in the city of Thessaloniki active between 1342 and 1350. They held great political sway in the city for the 8 years they were active and were known to have attacked prominent aristocratic members of the city in an effort to redistribute their wealth, with some sources even labelling it a "social reform" program. ${ }^{84}$ The context, including the social situation in Thessaloniki and Constantinople and the role of the Zealots, is key to understanding are key to understanding Kokkinos' concerns. In 1347, the Zealots in Thessaloniki were preventing Palamas from taking up his new position as archbishop of the city. The preceding few decades of Byzantine spiritual life had been dominated by the rise of Hesychasm and its opponents. Palamas was one of the great leaders of the Hesychast movement. ${ }^{85}$ By 1351, a church synod decree redefined the Orthodox doctrine by accepting the Hesychast view, the model that Palamas had defended, and Palamas was canonized

\footnotetext{
79 Talbot, Miracle Tales from Byzantium, 375 (Chapter 20).

${ }^{80}$ Ibid., 369 (Chapter 19).

${ }^{81}$ For more information on the idea of outsiders and "otherness" in the mid-to-late Byzantine Empire; see, D. Jacoby (ed.), Latins, Greeks and Muslims: Encounters in the Eastern Mediterranean 10 - 15th Centuries (London, Routledge, 2009). Especially the chapter titled "The Byzantine Outsider in Trade" by David Jacoby is a good illustration of this phenomenon.

${ }^{82}$ Angeliki E. Laiou, "Saints and Society in the Late Byzantine Empire", in Charanis Studies: Essays in Honour of Peter Charanis, ed. Angeliki E. Laiou (New Brunswick, N.J., Rutgers, 1980), 84.

${ }^{83}$ Talbot, Miracle Tales from Byzantium, 365 (Chapter 19).

${ }^{84}$ For more information on this, see Shevcenko, "Nicolas Cabasilas" "Anti Zealot" Discourse" in Dumbarton Oak Papers 11, 1957.

${ }^{85}$ Meyendorff, "Spiritual Trends in Byzantium in the Late Thirteenth and Early Fourteenth Centuries”, 97.
} 
as a saint. ${ }^{86}$ The hagiography that Kokkinos wrote about Palamas was written before his canonization, and it was precisely this result which Kokkinos was aiming for with his praisefilled writings about Palamas.

Kokkinos' writings offer a glimpse into the social world of Constantinopolitan city life. Talbot argues Kokkinos shows how the "vainglorious, unstable and flighty women of the sort nurtured by Constantinople in our days" were making malicious comments towards Palamas, even though they were not informed about him. ${ }^{87}$ Talbot's argument appears sensible given that Kokkinos continues to discuss how these women of the "so-called nobility" were concerned only with idle gossip, bad language and achieving superfluous fame in a good or bad way. ${ }^{88}$ These "women" appear to be the anti-Palamite women such as Irene Choumania, the wife of the deceased John Palaiologos. ${ }^{89}$ In a hagiography centred on Palamas, it is not surprising that the anti-Palamite populace is criticized quite harshly by the author; yet, these comments do reveal some important information about the different views that existed on society and morals.

With this in mind, the views of Kokkinos towards the Zealots appear a little more nuanced. Recent scholarship suggests that while the Zealots themselves did not ardently support the lower-classes on a theoretical basis, many people acting on their behalf and supporting them indeed were not part of the aristocracy and were interested in the redistribution of wealth on a more equal basis. ${ }^{90}$ Kokkinos, being a staunch supporter of Palamas, paints a negative picture of the Zealot factions and all of their self-professed objectives. This could be read as a belief in retaining the status-quo that existed in Thessaloniki, which heavily favoured a select few aristocratic families. Although when contrasted with his negative commentary on aristocrats in general, Kokkinos' views indicate perhaps that his negative portrayal of the Zealots was not associated with their so-called "social reform" agenda but was instead more to do with their opposition towards Palamas. After all, the text which contains this information was a sort of panegyric towards Palamas himself. The true viewpoints of Kokkinos may never be fully understood given the complexity of the situation at hand, yet it is clear that he was trying to compose a text which featured many references to a period of the acute social and political crisis in the city of Thessaloniki, and inevitably he ends up getting tangled up in it too. In scope of this analysis, the above is comparable to the commentary of Athanasios' on Andronikos' reform policies. In both cases the individuals (Athanasios and Kokkinos) are religious figures trying to reconcile their socio-economic opinions with their high social positions and religious background. In the case of Kokkinos, it seems fitting to argue that his condemnation of the Zealots lies almost entirely within scope of the religious and personal (relating to Palamas) disagreements he has with them (which is also inherently political), rather than their agenda of social reform. His sharp criticism of high-society and its moral degeneracy mentioned above

\footnotetext{
${ }^{86}$ Dirk Krausmüller, "The Rise of Hesychasm”, in The Cambridge History of Christianity, vol. 5: Eastern Christianity, ed. Michael Angold (Cambridge: Cambridge University Press, 2006), 101.

87 Talbot, Miracle Tales from Byzantium, 355 (Chapter 16).

${ }^{88}$ Ibid.

${ }^{89}$ Ibid., 435.

${ }^{90}$ Malatras, "The Myth of the Zealots", in Byzantiaka 30, 237.
} 
indicates that he may have in actuality been less against the idea of a generalized socio-economic reform of society than his writings otherwise indicate. Alas, he necessarily felt obliged to commit to becoming a full-on critic of the Zealots, social agenda or not, due to the other reasons mentioned above.

Overall, Athanasios and Kokkinos, two patriarchs of Constantinople, both provide us with a spectrum of information on the Byzantine society, especially associated with the two major cities of the empire, Constantinople and Thessaloniki. Kokkinos' negative comments towards the nobles of Constantinople are comparable to Athanasios' negative remarks towards the same segment of society from half a century earlier. Although Athanasios' criticism is directed more against the profiteering middlemen and traders, many of these ventures in the Palaiologan period were controlled or directly administered by the aristocracy. ${ }^{91}$ In the fourteenth century, the traditional sources of wealth of the aristocracy, countryside land, had declined in value ${ }^{92}$ and they had turned increasingly to investments in trade and banking ventures. ${ }^{93}$ This was coupled with greater urban investment by the aristocracy, which was also influenced by territorial shrinkage. ${ }^{94}$ Kokkinos' criticism here resonates more within the cultural and moral deterioration he has identified within the high echelons of Constantinopolitan society, as can be inferred from his partitioning of society mentioned above, providing another glimpse of his opinions on urban society.

Nonetheless, the two patriarchs both positioned themselves closer to the common, "godfearing" people, than to the wealthy or aristocratic classes, although the political reasons for such a stance should not be completely ignored. Still, this is most probably not an isolated trend among spiritual leaders, as Christianity in general aligns itself with the poor. Another interesting similarity is the slightly xenophobic attitudes which they both portray. Athanasios blames the "Latins" (Westerners) for most of Constantinople's grain price raising and profiteering activities, even though many Byzantine middlemen were involved in such activities and were making lucrative profits. Athanasios somewhat ignores his fellow Romans, while painting a very grim picture of these "Latins." Kokkinos' hagiography also shows how a sharp dichotomy existed between the Romans and foreigners, or the 'others.' Kokkinos described a foreigner coming to Thessaloniki from a non-Greek speaking region with different practices and being viewed with deep suspicion. These comments show that Kokkinos, just like Athanasios, was concerned about "outsiders", indicating a shared suspicion of especially the Latins, who were basically public

\footnotetext{
${ }^{91}$ The aristocracy is defined as laymen who formed the ruling elite of society, generally described by the term dinatoi, meaning 'the powerful'. Angeliki E. Laiou, "The Byzantine Aristocracy in the Palaiologan Period: A Story of Arrested Development", in Viator 4 (1973), 132.

${ }^{92}$ In the fourteenth century demographic and military factors dramatically reduced manpower available for countryside labour. This resulted in peasants gaining a bargaining power as their value greatly increased, and as a result in the fourteenth century we frequently encounter dependent peasants contesting their landlords' rights. Kostis Smyrlis has analyzed two such cases in his article; Kostis Smyrlis, "Our Lord and Father: Peasants and Monks in mid-Fourteenth Century Macedonia", Travaux et Mémoires 16 (2011), 790.

${ }^{93}$ Nevra Necipoglu, "The Byzantine Aristocracy during the Period of Ottoman Conquests", In Aristocracies of the Northern Mediterranean Regions in the Medieval and Early Modern Periods, ed. Angeliki E. Laiou and Pierre Toubert (Fondation des Treilles/France, June 1996), 12.

${ }^{94}$ Ibid., 13-14.
} 
enemy number one in Constantinople since the incidents of 1204. The liberation of 1261 was not so long ago in this period, and further Church hostilities had also commenced since. One of the primary reasons for the similarity in attitudes shown by both of these patriarchs may stem from their position as ardent anti-Unionist patriarchs. They had both fought against any sort of church union with the Latins, which may have fueled their hatred of anyone different, foreign and unOrthodox.

Athanasios' letters contained a greater amount of moralizing information defending the 'poor people' than Kokkinos' hagiography. One of Athanasios' comments sums his viewpoint up nicely: "God decreed that men should be ruled by men, lest, like fishes, the stronger swallow up the weaker with impunity." 95 He wanted the emperor to rule with the common people's interests in mind. According to Boojamra, Athanasios' main concern was to show that the common people were suffering the most from the empire's problems, and that despite this, they received the least assistance from the state and emperor. ${ }^{96}$ When viewed as a whole, his letters show that he was dedicated to improving their living conditions. Overall, Athanasios' letters supply a greater quantity of technical and direct information about to the social and economic atmosphere of the Byzantine capital, yet Kokkinos' subtle additions to this subject are also useful in illuminating the socio-cultural side of events, especially for the turbulent eight years (1342-1350) in Thessaloniki. These texts furnish us with information about Byzantine society through the lenses of these two patriarchs. For example, when Athanasios thanks the emperor for having set up the grain regulation commission which he had suggested, there is no reason to doubt that this commission was set up by the emperor. Athanasios' letter continues on from this to suggest further improvements, so there is no reason whatsoever for him to be distorting this initial piece of information. Thus, it can be taken with relative safety as constituting a fact about fourteenth century Constantinopolitan economic life. On the other hand, some things which he describes, especially more personal stuff, such as his own setting up of a soup kitchen in the capital will remain bit vaguer accuracy-wise due to there existing no reliable source to cross-check this exact fact with.

In general, the religious positions of these two figures provided both a platform for the expression of certain socio-economic policies, while simultaneously serving as a barrier for them being able to reveal their true opinions on such matters, as they were subject to religious constraints and the sensibilities of the high-ranking positions which they occupied. It is possible to gain a glimpse into such internal struggles during Athanasios' commentary on Andronikos' economic policies, or Kokkinos' criticism of the Zealot factions in Thessaloniki. A more normative view of the perceptions of high religious figures can be crafted by reading beyond their political and cultural biases, to a understand the authors' positions on social and economic issues.

\footnotetext{
${ }^{95}$ Athanasios I, 187 (Letter 74).

${ }^{96}$ Boojamra, Church Reform in the Late Byzantine Empire, 155.
} 


\section{Bibliography}

Athanasios I. The Correspondence of Patriarch Athanasios I: Letters to the Emperor Andronikos II, Members of the Imperial Family, and Officials. Trans. Alice-Mary Talbot. CFHB Vol VII, 1975.

Boojamra, John L. Church Reform in the Late Byzantine Empire: A Study for the Patriarchate of Athanasios of Constantinople. Analekta Vlatadon 35. Thessalonike: Patriarchal Institute for Patristic Studies, 1982.

Charanis, Peter. "On the Social Structure and Economic Organization of the Byzantine Empire in the Thirteenth Century and Later". Byzantinoslavica 12, 1951.

Efthymiadis, Stephanos. The Ashgate Research Companion to Byzantine Hagiography: Volume II: Genres and Contexts. Ashgate Publishing, 2013.

Krausmüller, Dirk. "The Rise of Hesychasm”. In The Cambridge History of Christianity, vol. 5: Eastern Christianity. Ed. Michael Angold. Cambridge: Cambridge University Press, 2006.

Laiou, Angeliki E. The Foreign Policy of Andronikos II 1282-1328. Cambridge, Mass.: Harvard University Press, 1972.

Laiou, Angeliki E. "Saints and Society in the Late Byzantine Empire". In Charanis Studies: Essays in Honour of Peter Charanis. Ed. Angeliki E. Laiou. New Brunswick, N.J., Rutgers, 1980.

Laiou, Angeliki E. "The Byzantine Aristocracy in the Palaiologan Period: A Story of Arrested Development. In Viator 4, 1973.

Laiou, Angeliki E. "The Provisioning of Constantinople During the Winter of 1306-1307". Byzantion 37, 1967.

Malatras, Christos, "The Myth of the Zealots”, Byzantiaka 30, 2012.

Meyendorff, J. "Spiritual Trends in Byzantium in the Late Thirteenth and Early Fourteenth Centuries". The Kariye Djami, vol. 4. Ed. P. Underwood. Princeton, N.J., 1975.

Necipoglu, Nevra. "The Byzantine Aristocracy during the Period of Ottoman Conquests". In Aristocracies of the Northern Mediterranean Regions in the Medieval and Early Modern Periods. Ed. Angeliki E. Laiou and Pierre Toubert. Fondation des Treilles/France, June 1996.

Nicol, Donald M. Church and Society in the Last Centuries of Byzantium. Cambridge: Cambridge University Press, 1979.

Shevcenko, Ihor. "Nicolas Cabasilas' "Anti Zealot" Discourse," Dumbarton Oak Papers 11, 1957, pp. 81-171.

Smyrlis, Kostis. "Our Lord and Father: Peasants and Monks in mid-Fourteenth Century Macedonia”. In Travaux et Mémoires 16, 2011.

Talbot, Alice-Mary and Scott F. Johnson. Miracle Tales from Byzantium. DOML 12. Cambridge: Harvard University Press, 2012.

Talbot, Alice-Mary. Faith Healing in Late Byzantium: The Posthumous Miracles of the Patriarch Athanasios I of Constantinople by Theoktistos the Stoudite. Brookline, Mass.: Hellenic College Press, 1983. 